\title{
Pharmacoeconomy: an indispensable tool for the rationalization of health costs
}

\author{
Camila Alves Areda1, Roni Cléber Bonizio², Osvaldo de Freitas ${ }^{1, *}$ \\ ${ }^{1}$ Faculty of Pharmaceutical Sciences of Ribeirão Preto, University of São Paulo, ${ }^{2}$ School of Economy, Administration and \\ Accounting of Ribeirão Preto, University of São Paulo
}

\begin{abstract}
Due to the considerable increase in public expenditure with health issues, mainly regarding drugs, several countries, including Australia and England, have already implemented, or are in the process of discussing the adoption of measures to ensure the quality of health care provided to the population. One of the less harmful strategies, rarely used in Brazil, is the adoption of economic techniques applied to health, more specifically, pharmacoeconomic analysis. This paper aims to contribute to the dissemination of concepts and techniques of economic analysis with a view to incorporate these into policy decisions of expenditure rationalization and the search for clinical efficiency. It includes a literature review covering the types of costs and benefits in health issues, the methodologies of pharmacoeconomic analysis, cost-minimization, cost-benefits, cost-effectiveness and cost-utility analysis, as well as its main characteristics, advantages, disadvantages and applicability.
\end{abstract}

Uniterms: Pharmacoeconomy. Pharmacoeconomics analysis.

Em razão do aumento considerável no gasto público com saúde, principalmente no que tange a medicamentos, vários países, como Austrália e Inglaterra, já implementaram ou estão em fase de discussão da adoção de medidas visando garantir a qualidade do atendimento prestado à população. Uma das estratégias menos danosas, mas ainda incipiente no Brasil, é a adoção de técnicas de análises econômicas, mais especificamente, a avaliação farmacoeconômica. Neste contexto, este trabalho visa contribuir com a disseminação dos conceitos e técnicas de análises econômicas com a perspectiva de que possam ser incorporadas nas decisões políticas de racionalização dos gastos e na busca da eficiência clínica. Para tanto, este artigo apresenta uma revisão bibliográfica contemplando os tipos de custos e benefícios em saúde, as metodologias de análise farmacoeconômicas, quais sejam: análise de minimização de custo, de custo-benefício, de custo-efetividade e de custo-utilidade, assim como suas principais características, vantagens, desvantagens e aplicabilidades.

Unitermos: Farmacoeconomia. Análise farmacoeconômica.

\section{INTRODUCTION}

Pharmacoeconomy is a sub-area of Health Economics that associates clinical concepts of efficacy, safety and quality of various procedures in health care, with measures of economic cost. Thus, it can be defined as an "application of economic theory to pharmacotherapy" or "economic evaluation of drugs" or, it could be placed at

*Correspondence: O. Freitas, Departamento de Ciências Farmacêuticas, Faculdade de Ciências Farmacêuticas - USP/Ribeirão Preto, Av do Café, s/n, 14040-903 - Ribeirão Preto - SP, Brasil. E-mail: ofreitas@fcfrp.usp.br the interface between two large traditional areas, health and economy (Castilho, 1995).

It is a tool that helps to select more efficient options (with a good cost/effect relationship) and could help in the distribution of health resources in a more just and balanced manner. Pharmacoeconomy contributes to the rational use of medicines by incorporating cost to questions on safety, efficacy and quality of different medical therapies, and to the search for a better relationship between costs and results. Although employing the word "pharmaco" (drug) in its nomenclature, it presents tools that can be equally utilized for the assessment of medicines, health programs and even of administrative systems, provided that the 
characteristics inherent to each application are observed (Zanini et al., 2001).

In constituting an area of intersection, "conflicts" are unavoidable due to the diverse forms that health is considered. Traditionally, the professions related to the health area are centered on individualistic ethics, according to which health has no price and a life saved justifies all effort. On the other hand, the economy is underpinned by the ethic of common welfare or social ethics. The origin of these differences resides in the attitudes of each group regarding resource utilization, but both have a vision for the future that incorporates resource rationalization and improved care rendered in health issues (Del Nero, 2002). Countries that have invested in the training and specialization of human resources to act at the economy/health interface have achieved higher rationalization rates in the process of management and quality of health services.

\section{HEALTH PANORAMA}

Management of the health/illness processes has required ever higher amounts of resources especially those dedicated to the purchase of medicines. This constant increase can be attributed to several factors including take up of new technologies, population aging and the consequent rise in chronic-degenerative diseases, efforts to increase access to health systems, strategies for the promotion of new medicines directed at both the prescribing and the consuming classes.

The increased public expenditure with medicines has been a cause for concern among governments, because in general these rises are higher than inflation or the growth in Gross Domestic Product - GDP (Brussels, 2006).

In the USA, health expenses surpassed 1.3 trillion dollars in 2000, reaching 2 trillions in 2006, a value equivalent to $16 \%$ of the GDP. According to projections, this percentage is set to increase to $20 \%$ by 2015 (Lottenberg, 2007).

In the United Kingdom, the growth in health expenses is higher than in other sectors of the economy. In 2001 and 2002, expenses with health represented $17 \%$ of public expenditure, the greatest proportion since 1948 (Leatherman et al., 2003).

Medical drugs consume a considerable portion of the country's resources, having a strong impact on overall health expenses. In Canada, total expenditure with medicines increased $11 \%$ in 2005 , reaching 24.8 billion dollars. This expense, the second largest after that of hospitals, has been higher than expenses with medical doctors since 2000 (Canadian Medical Association Journal, 2006; Buske, 2000, 2004).
In Brazil, according to the National Health Fund (Vieira, Mendes, 2007), expenses with health are evolving in the same way, although not linearly.

In 2006 the actual expense of the Health Ministry, discounting inflation's impact, reached 23.6 billion reais at 2001 prices. In the period between 2002 and 2006, the portion of the health budget earmarked for the acquisition of medicines increased by $123.9 \%$, a sum equivalent to $11 \%$ of the total expenditure with health issues in 2006 . Over the same period, total expenses by the Health Ministry increased $9.6 \%$ (Vieira, Mendes, 2007).

In the face of increased expenses and the need of at least maintaining the quality of health services, governments will be obliged to adopt sustaining financial measures including tax hikes, cut backs in other areas and charging users (Brussels, 2006).

Nevertheless, some countries are adopting less damaging strategies, such as the adoption of economic analysis during the process of choosing higher priority alternatives (Johannesson, Le Lorier, 1996; Briggs, Gray, 1999). Such analysis can supply information to help managers compare alternatives and decide about the best option for their program needs, in a bid to associate rationalization of expenses to clinical efficiency. Clinical efficiency means maximal attention to quality and user satisfaction, with the least possible social costs (Robinson, 1993a; Russel et al., 1996).

Australia was one of the first countries to incorporate economic studies in the devising of therapeutic guides and in the adoption of new health practices. In 1993, the Australian government, through the Pharmaceutical Benefits Advisory Committee, determined that requests for the inclusion of new medicines onto the list of those freely distributed to the population, should be accompanied by an economic analysis for comparison with current therapeutic alternatives (Grobler, 1999).

England created the National Institute for Clinical Excellence (NICE), an institution responsible for the evaluation of new health technologies always incorporating a critical review of existing economic studies (Brasil, 2008).

Canada, United States and some European countries have recommended economic analyses in the registration of new products and in discussions about policies to be adopted.

In Brazil, public and private institutions, academic or otherwise, base recommendations for the inclusion of new drugs in therapeutic guides on medical facts. However, the utilization of pharmacoeconomic information to support political decisions remains incipient. 


\section{HEALTH ECONOMY}

Del Nero (2002, pg. 19) defines health economy as "the branch of knowledge that has as its objective the optimization of health actions, meaning the study of optimal conditions for the distribution of available resources to assure the best health assistance and conditions to the population, taking into account the limited means available".

The World Health Organization divides health economy into Health Macroeconomics and Health Microeconomics. The first aims to develop economic studies on health in general and its relations with other socioeconomic sectors whilst the second is dedicated to the study of different health components (WHO, 1976).

Health economics exploit relevant topics in its field of application: the role of health services in the economic system; the system of production and distribution of health services; the ways of measuring the impact of investments in health; the study of health indicators and levels correlated to economic variables; the employment and salary of healthcare professionals and the work force available; the health industry in advanced capitalism; the behavior of service providers and their relations with the consumer; the cost-benefit analysis, cost-effectiveness analysis, and cost-utility analysis of services or specific goods (Del Nero, 2002), such analysis being the major components of pharmacoeconomy.

In the commonly used definition established by Townsend (1987), pharmacoeconomy represents the "description and analysis of medical therapy cost to health systems and society". In this broad concept, the term includes all aspects of the medical economy: its impact on society, on the chemo-pharmaceutical industry, on pharmacies, on national formularies, stating that nearly all areas related to medical drugs are connected with economic issues (Sacristan Del Castillo, 1995).

The International Society for Pharmacoeconomics and Outcomes Research - ISPOR defines pharmacoeconomy as the "field of study that evaluates individual, enterprise and market behavior in relation to the use of products, services and pharmaceutical programming, and frequently focuses on costs, and the consequences of its utilization" (Pashos, Klein, Wanke, 1998).

Pharmacoeconomy comprises the valuation of technical yields, of clinical efficiency, security, economic efficacy, organizational impact and of its social consequences and ethical implications (Mossialos, 1997).

Pharmacoeconomic evaluation identifies, quantifies and compares costs (resources used for pharmaceutical products and services) and consequences (economic, clinical and humanistic) of its utilization, thus allowing identification of the results of actions in the health area as an economic indicator of its efficiency or efficacy, in addition to helping optimize resource use and decision making. Its costs represent financial investment in health. Traditionally, health costs have been classified as direct, indirect and intangible, fixed and variable (Drummond et al., 1997). Direct costs are those directly associated with medical care and medical drugs (Robertson, Lang, Hill, 2003), and may be classified into: a) sanitary or medical, related to drugs or medical care (purchase, cost of medicine supply and administration, hospitalization, consultations, diagnostic evidence); and b) non-sanitary or nonmedical, encompassing those related to the furnishing of medical services including patient transportation, family care, and special nutrition (Carlos et al., 2001).

Indirect costs are related to loss of the productive capacity of individuals faced with the process of getting sick or of an early death. They represent loss of working days, inability to perform professional activities, loss of time on trips to receive health care, and premature death secondary to disease (Bombardier, Eisenberg, 1985; Villar, 1995; Lew, Forgia, Sulvetta, 1996). Due to the difficulty of objectively estimating indirect costs, some institutions, including the Australian Pharmaceutical Benefits Advisory Committee, have set up directives that exclude indirect costs (Department of Health and Aged Care, 1994). Nevertheless, the National Institute for Clinical Excellence, 2001, recommends that these costs be calculated separately so that the impact of their exclusion can be evaluated (Nice, 2001).

Intangible costs are those associated with pain and suffering, and are the most difficult to quantify and evaluate, although up to a certain point they are incorporated in the services ascribed to illnesses that reflect quality of life (Robertson, Lang, Hill, 2003).

Costs may be variable or fixed. Fixed costs are those that do not vary with the amount of goods or services rendered, while variable costs are those that vary with the amounts produced (Mankiw, 2001).

The concept of opportunity or social costs reflects the scarcity or limitation of resources. It is related to benefits derived from the utilization of resources by the alternative of best use. Therefore, it is a measure of the sacrifice made by society for the use of resources in a given program, as they will no longer be available for use in others (Griffiths, 1981; Mills, Drummond, 1985).

The consequences or benefits, in turn, may be economic (economy or economic benefits), clinical, i.e. a consequence of a pharmacological treatment or strategy (deaths, morbidities and other specific clinical indicators) or humanistic, resulting from the disease or treatment in 
the patient's functional condition or their quality of life measured according to diverse dimensions (satisfaction, general health, physical functions, social functions, life expectancy or quality, etc.) (Venturini, Johnson, 2002; Zanini et al., 2001).

The economic benefits associated with improved patient health conditions can be measured in the following ways (Reinhardt, 1997): direct benefits, representing resources not spent in relation to costs resulting from medical assistance, for example cases of mammary cancer avoided by investing in a prevention program; and indirect benefits, which are gains in productivity and to society. Health recovery and deaths prevented increase the number of people able to work and produce for the benefit of society.

For a full understanding of the techniques of economic evaluation, it is important to also describe the concepts of efficacy, effectiveness and efficiency.

Efficacy refers to the benefits, consequences and results (outcomes) of drugs utilized under ideal conditions, that is, during application in clinical trials mainly using rigorous criteria of patient selection, the follow up of their clinical evolution and strict compliance with their therapeutic regime. Effectiveness measures the results of the utilization of medicines in daily clinical practice, thus evaluating it under habitual real conditions. It should be noted that effectiveness is frequently lower than efficacy. Efficiency represents the relation between the financial resources (costs) and outcomes, utilized in a given intervention (Jolicoeur, Jones-Grizzle, Boyer, 1992; Sacristan Del Castillo, 1995; Bootman, Townsed, Mcghan, 1996).

From a health perspective, a program or treatment is considered efficient when it attains the maximum degree of health possible by the given resources or, when the result obtained by the choice, is at least equal to the opportunity cost. It is also efficient when, comparing options that produce the same result, it is elected the least expensive (Sacristán et al., 2004).

According to Carlos et al. (2001) and Gold et al. (1996), the economic evaluation is carried out prior to the decision on its implementation, so that costs and effects of its application will occur in future. In these cases, when the costs and effects are produced in a period longer than one year, it will be necessary to transform them into units equivalent to those of the year zero (the time when the evaluation is performed). This correction is justified in part because society values results about health more when reached in the present than those that might be obtained in the future, and because in general, one prefers to postpone costs, rather than carry them in the present. An extensive debate prevails in the literature about an appropriate discount tax that should reflect the individual's preference to negotiate future gains (or losses) against present ones. The Cost-Effectiveness Panel recommends a discount tax of 3\% (Russel et al., 1996).

In pharmacological evaluation, several methods can be utilized, from simple cost minimization analysis to more comprehensive cost-benefit, cost-effectiveness and cost-utility analysis. The methods vary according to the objective and the analysis perspective. Therefore, pharmacoeconomic analysis do not decide on medicinal policy, but play an important factor in decision taking.

Data for pharmacoeconomic analysis are obtained from controlled clinical assays (randomized studies), observational studies, economic models (primary sources), and retrospective studies, the opinion of a clinical specialist, evaluations of the medicine uses, and the literature (secondary sources) (Zanini et al., 2001). The use of these sources depends on published data, the quality of retrospective data bases, human and monetary resources, and the relative importance of the decision (Zanini et al., 2001).

\section{TYPES OF PHARMACOECONOMIC EVALU- ATION}

\section{Cost Minimization Analysis}

Cost Minimization Analysis (CMA), one of the simplest economic evaluations, is utilized when the result of two or more interventions are the same in terms of their clinical consequences. In CMA, only costs are submitted for comparison, because the efficacy or effectiveness of comparable alternatives are equal. (Eisenberg, 1989; Jolicoeur, Jones-Grizzle, Boyer, 1992; Sacristan Del Castillo, 1995; Bootman, Townsend, Mcghan, 1996; Drummond et al., 1997). This approach is justified when alternatives of comparable programs or therapies produce clinically equivalent results, as in decision taking of pharmotherapeutic guides (Carreira-Hueso, 1998; Drummond, 1991). Thus, the first critical step prior to conducting a CMA is to determine the therapeutic equivalence of the interventions (Robertson, Lang, Hill, 2003). When intervention results differ, it is not possible to proceed to cost minimization analysis. An example of CMA is the analysis of administration costs of the same medicine given using different routes of administration (Przybylski et al., 1997).

\section{Cost Benefit Analysis (CBA)}

Cost Benefit Analysis (CBA) establishes the relationship between costs associated to treatment and financial benefits generated by it. All cost (investments) and benefits (consequences) of alternatives are measured in 
monetary terms so that it will be possible to verify whether the benefits exceed the expenses for each intervention. Among other aspects, the return of applied resources in a health issue may be compared with gains obtained by investments made in other areas of the economy (Robinson, 1993a). Examples: (i) the relationship of treatment costs and the economy of resources resulting from shorter patient hospital stay; (ii) the costs of a vaccination program and the resources yielded by the reduction of absences from work or the number of hospital admissions; (iii) the costs of a program of early treatment of diseases versus delayed treatment or its complications etc. (Zanini et al., 2001).

The results of cost-benefit analysis are present in the form of liquid benefits, that is, benefits of the intervention minus the costs of intervention (Brasil, 2008). This type of instrument evaluates the economic viability of social projects, it can be applied to a given program or to various alternative ones in order to compare them in terms of their “social profitability'. This presumes the concept of progra$\mathrm{ms}$ in the social area (health, education etc.) as investments in human capital, in the sense that these programs, whether for empowering or rendering the work force healthier or increasing their productivity, boost the productivity of the economic system as a whole. The theoretical basis of this technical instrument therefore becomes evident: the theory of human capital and the methodology of the economic analysis of investments (Ugá, 2002).

Thus, these studies show the theoretical advantages of facilitating choices between health and non-health programs (for example, between subsidizing a new drug and increasing funds for school transportation) (Brinsmead, Hill, 2003), and of providing subsidies to public administrators and to society for taking better informed decisions and enabling the optimization of resource utilization.

This type of analysis has the inherent inconvenience of the difficulty attributing monetary value to the results and to life, not permitting simultaneous comparisons of products with more than one indication. Intangible benefits, such as the subjective health expression of each patient and the value of human life, are obviously very difficult to be expressed in monetary terms. Furthermore, the evaluation of benefits to persons that do not have an economic activity becomes impaired. This type of analysis has often been criticized for ignoring important benefits resulting from health programs and for concentrating on items of easy measurement. Initially, it was the most used analysis, but due to the difficulty of attributing monetary values to human life, cost-effectiveness is currently more utilized (Carreira-Hueso, 1998; Drummond, 1991; Robinson, 1993b).

\section{Cost Effectiveness Analysis (CEA)}

Cost Effectiveness Analysis (CEA) concerns the relationship between the cost of a treatment, measured in monetary units, and its clinical benefits (effectiveness) to the patient. Results are expressed in non monetary units, that is, in terms of improved health or natural units (lengthened life span, number of lives saved, clinical cures, days free of symptoms or pain, cost/hour of nursing time, cost/mercury millimeter of altered arterial blood pressure) (Drummond, Jefferson, 1996; Walley, Haycox, 1997; Zanini et al., 2001). Thus, the unit of measurement selected will depend on the objective of the program or treatment evaluated (Pinto-Prades, Ortún-Rubio, Puig-Junoy, 2001).

In general terms, CEA is the most appropriate technique when the choice has to be made between two or more competing options, for which the gains expected in health can be expressed in terms of a measuring common effect (Lopert, Lang, Hill, 2003). Therefore, CEA is always comparative and considered in the choice of the best strategy to attain the same objective (Detsky, Naglie, 1990; Drummond, 1994; Ugá, 2002). Examples include the relationship between costs of treatment by different antihypertensive agents and the respective degrees of effectiveness in decreasing the patient's arterial pressure, or costs of different chemotherapy treatments against cancer and their respective degrees of effectiveness in saving or extending lives (Zanini et al., 2001).

CEA represents the type of analysis most utilized in pharmacoeconomy, because it enables the use, in daily practice, of the same units utilized in clinical assays.

The calculation of the cost-effectiveness ratio expresses the additional cost required to reach an extra unit of clinical benefit and is expressed by the difference between the cost of two interventions, divided by the difference between their consequences in terms of health (effectiveness) (Brasil, 2008).

Another measurement unit of cost-effectiveness is the quality of life related to health (QLRH). The two major types of QLRH are: a) those which are specifically named, formulated to evaluate improvements in the quality of life produced by a specific treatment; and b) those generically named, developed to evaluate variations in life quality produced by any type of intervention (Pinto-Prades, OrtúnRubio, Puig-Junoy, 2001).

The analysis of cost-effectiveness however, has limitations. As already noted, it may be useful for determining expense priorities in different treatments for the same condition (technical efficiency), but is less applicable in decisions concerning treatment for different diseases. It is not possible to compare programs (or even within the same 
program) when a common measure does not exist. One cannot compare cost-effectiveness of an antihypertensive therapy and one for asthma, where effects of treatment are described in terms of reduction of blood pressure in the first case, and the percentage of increased forced expiration volume, in the second (Lopert, Lang, Hill, 2003).

However, in several studies that work with effects (such as the number of deaths prevented) and not with products (vaccination, number of houses attended with sewers, etc.) this restriction may be effectively overcome in the sense that strategies of intervention are compared with totally distinct products (expansion of the health system, immunization, maternal-infant care, for example) (Ugá, 2002).

\section{Cost Utility Analysis (CUA)}

Cost Utility Analysis (CUA) considers the relationship between costs of a treatment and its benefits to the health-related quality of life of the patient (utility), as well as the risks of adverse drug reactions. This method combines patient satisfaction and preference with costeffectiveness analysis. It is applicable in studies aimed at comparing different treatments mainly targeted to chronic patients. Examples include relationship between the cost of different cancer treatments and their respective life quality indexes, related to patient health during the extra years that they have gained; cost for a rheumatoid arthritis treatment and the health-related quality of life the patient started to lead following pain reduction and improved mobility. However, it does not allow comparisons between different sectors, for example, health costs in relation to education (Walker, 2001).

In Cost Utility Analysis, cost to obtain "one year of healthy life" is calculated with different treatments that is, it incorporates the amount and also the quality of life in the years that were saved by means of a treatment. The results (output) are expressed as the cost for the "years of healthy life" or "years of life adjusted for quality "(QALY - quality-adjusted life-years). QALYs are calculated by the years of life gained, multiplied by a quality index, verified by means of specific questionnaires. Modern medicine is concerned about the improvement of life quality and not only about longevity of life (Drummond, 1991; Robinson, 1993b).

The use of life expectancy adjusted for quality enables the evaluation of situations in which there is increased survival under health conditions that are not perfect or therapies that do not alter survival, but improve quality of life (Brasil, 2008).

CUA is presently the economic evaluation approa- ch preferred by specialists, mainly because it allows the comparison of different programs or treatments without the ethical problems occurring in CBA over attributing monetary values to health. The use of lists of treatments and health programs classified according to their cost per QALY, has helped the setting of priorities in health issues. The lower cost treatments per QALY should be implemented first, and those with higher cost per QALY should be considered of lesser priority. However, although useful, this cannot be the sole criterion employed in the setting up of health priorities (Pinto-Prades, Ortún-Rubio, Puig-Junoy, 2001).

Thus, pharmacoeconomic analysis considers the economic factors in the utilization of medicines, but does not exclude clinical and humanistic results as important subjects for evaluation. The real value of an intervention or policy can only be found when all dimensions of the result are measured and taken into consideration. Viewed in this manner, the economic criterion cannot perform the major role.

Table I illustrates, in summarized form, the major characteristics of each type of analysis.

\section{SENSITIVITY ANALYSIS}

Sensitivity analysis takes into account the uncertainties common to economic evaluations of health, since the results found in clinical practice can vary in relation to results reported in the medical literature. Thus, this type of analysis recalculates the cost-effectiveness ratios obtained, modifying one or more parameters of the study. Examples of variables are the degree of effectiveness of the intervention, the natural course of the disease, the costs related to the treatment, the expected result in life quality, among others.

The Panel of Cost-Effectiveness in health recommends the use of this technique in economic health evaluations and suggests the calculation of all parameters or variables of the model whose estimation are not precise or whose values may vary in different settings (Brasil, 2008).

Sensitivity analysis can be conducted modifying one or numerous variables of the model simultaneously.

If, on varying the values of a given parameter the chosen strategy remains stable, one states that the model is insensitive to this parameter and the lack of precision in its estimate does not decrease the validity of the conclusions obtained by the model (Reinhardt, 1997).

In developed countries, cost analysis are frequently employed for managers to gain adequate information when defining and choosing priority interventions in the health area. 
TABLE I - Types of pharmacoeconomic analysis

\begin{tabular}{|c|c|c|c|c|}
\hline $\begin{array}{l}\text { Type of } \\
\text { Analysis }\end{array}$ & Characteristics & $\begin{array}{c}\text { Advantages (V) } \\
\text { Disadvantages (D) }\end{array}$ & $\begin{array}{l}\text { Measure of } \\
\text { Costs }\end{array}$ & $\begin{array}{l}\text { Measure of } \\
\text { Effects }\end{array}$ \\
\hline CMA & $\begin{array}{l}\text { Finds the program of least cost } \\
\text { among those of equal benefit }\end{array}$ & $\begin{array}{c}\text { Includes only limited costs (inputs) (D) } \\
\text { Rarely applicable (D) }\end{array}$ & Monetary Units & $\begin{array}{l}\text { Equivalent } \\
\text { Effects }\end{array}$ \\
\hline CBA & $\begin{array}{l}\text { Complete economic evaluation. } \\
\text { Costs and consequences must } \\
\text { be evaluated in monetary terms }\end{array}$ & $\begin{array}{l}\text { Permits a direct comparison between } \\
\text { the incremental cost of the program } \\
\text { and its incremental consequences in } \\
\text { commensurable measurement units (V) } \\
\text { Difficulty to define monetary value for } \\
\text { consequences in health issues (D) }\end{array}$ & Monetary Units & Monetary Units \\
\hline CEA & $\begin{array}{l}\text { Supplies the cost per specific } \\
\text { unit-program or years of life } \\
\text { saved }\end{array}$ & $\begin{array}{l}\text { Widely applicable due the ample } \\
\text { spectrum of possible clinical results (V) } \\
\text { Difficult to establish comparisons } \\
\text { between studies of different diseases, } \\
\text { due to differences in the measure of } \\
\text { primary effectiveness (D) }\end{array}$ & Monetary Units & $\begin{array}{c}\text { Clinical } \\
\text { Habitual Units }\end{array}$ \\
\hline CUA & $\begin{array}{l}\text { Supplies the cost for QALY or } \\
\text { a similar measure, including } \\
\text { the notion of the patient's } \\
\text { preference }\end{array}$ & $\begin{array}{l}\text { Permits a wide scale of results to be } \\
\text { combined in a summarized result (V) } \\
\text { Difficult to measure utilities (D) }\end{array}$ & Monetary Units & $\begin{array}{l}\text { Quantity and } \\
\text { Life Quality }\end{array}$ \\
\hline
\end{tabular}

$\mathrm{CMA}=$ Cost Minimization Analysis; $\mathrm{CBA}=$ Cost Benefit Analysis; $\mathrm{CEA}=$ Cost Effectiveness Analysis; CUA = Cost Utility Analysis; QALY = Quality Adjusted Life Years.

In: Venturini; Johnson, 2002, p 7.

In Brazil, as in other developing countries, this practice has not been adopted (Médici, 1994). The conducting of economic studies is still rare in the country and concentrated in academic institutions.

Arredondo and Damian, 1997, emphasized the need for identifying and controlling the costs of services as a priority problem for the system's organization. Therefore, it is important that the government and health systems become involved with the spreading of concepts and techniques of economic analysis, investing in the education and training of qualified human resources and stimulating the production of studies applying these tools, both in public and private sectors, and actually start to incorporate economic analysis into policy decisions on health issues.

\section{REFERENCES}

ARREDONDO, A.; DAMIÁN, T. Costos económicos en la producción de servicios de salud: del costo de los insumos al costo de manejo de caso. Salud Publica Mex, v.39, n.2, p.117-124, 1997.
BOMBARDIER, C.; EISENBERG, J.M. Looking into the crystal ball: can we estimate the lifetime cost of rheumatoid arthritis? J. Rheumatol., v.122, n.2, p.201-204, 1985.

BOOTMAN, J.L.; TOWNSEND, R.J.; MCGHAN, W.F. Principles of Pharmacoeconomics. 2.ed. Cincinnati: Harvey Whitney, 1996. 409 p.

BRASIL. Ministério da Saúde. Secretaria-Executiva. Área de Economia da Saúde e Desenvolvimento. Avaliação Econômica em Saúde: desafios para gestão no Sistema Único de Saúde. Brasília: Ministério da Saúde, 2008. 104 p.

BRIGGS A.H.; GRAY, A.M. Handling uncertainty in economic evaluations of healthcare interventions. Br. Med. J., v.319, n.7210, p.635-638, 1999.

BRINSMEAD, R.; HILL, S. Use of Pharmacoeconomics in prescribing research. Part 4: cost-utility analysis a useful tool? J. Clin. Pharm. Ther, v.28, n.4, p.339-346, 2003. 
BRUSSELS, R.W. Health spending rising faster than GDP in most rich countries. Brit. Med. J., v.333, n.60, p.60, 2006.

BUSKE, L. Drug costs surpass spending on physicians. Can. Med. Assoc. J., v.162, n.3, p.405, 2000.

BUSKE, L. Health care spending rises $4,6 \%$ in 2003. Can. Med. Assoc. J., v.170, n.3, p.325, 2004.

CANADIAN MEDICAL ASSOCIATION JOURNAL. Drug spending hits $\$ 24.8$ billion. Can. Med. Assoc. J., v.175, n.1, p.22, 2006.

CARLOS, I.C.C.; SIQUEIRA, R.L.C.L.; PESSOA, M.T.F.C.; ALMEIDA, R.F.C. Farmacoeconomia: guia breve. Fortaleza: Secretaria da Saúde do Estado do Ceará, 2001. $56 \mathrm{p}$.

CARREIRA-HUESO, F.J. Aplicación de los estudios farmacoeconômicos em el hospital. Med Clin, v.111, n.9, p.347-353, 1998.

CASTILHO, J.A.S. Farmacoeconomía y evaluación econômica de medicamentos: Introducción. In: CASTILHO, J.A.S.; LLACH, X.B.; FORNS, J.R. Farmacoeconomía: evaluación econômica de medicamentos. Madrid: Editores medicos, 1995. cap.1, p.19-30.

DEL NERO, C.R. O que é Economia da Saúde. In: PIOLA, S.F.; VIANNA, S.M., (Orgs.). Economia da Saúde: conceito e contribuição para a gestão da saúde. 3.ed. Brasília: IPEA, 2002. cap.1, p.5-21.

DEPARTMENT OF HEALTH AND AGED CARE. Guidelines for the pharmaceutical industry on preparation of submissions to the Pharmaceutical Benefits Advisory Committee: including major submissions involving economic analyses, 1995. Available at: <http://www.health. gov.au/pbs/pubs/pharmpac/gusubpac.htm>. Accessed on: 12 fev. 2004.

DETSKY, A.S., NAGLIE, I.G., A clinician's guide to costeffectiveness analysis. Ann. Intern. Med., v.113, n.2, p.147154,1990

DRUMMOND, M.F. Guidelines for pharmacoeconomics studies: the ways forward. Pharmacoeconomics, v.6, n.6, p.493-497, 1994.
DRUMMOND, M.F. Introducing economic and quality of life measurements into clinical studies. Ann. Med., v.33, n.5, p.339-344, 1991.

DRUMMOND, M.F.; JEFFERSON, T.O. Guidelines for authors and peer reviewers of economic submissions to the BMJ. Br. Med. J., v.313, n.7052, p.275-283, 1996.

DRUMMOND, M.F.; O’BRIEN, B.; STODDART, G.L; TORRANCE, G.W. Methods for the economic evaluation of health care programmes. 2.ed. New York: Oxford University Press, 1997. $181 \mathrm{p}$.

EISENBERG, J.M. Clinical economics: a guide to economic analysis of clinical practices. J. Am. Med. Assoc., v.262, n.20, p.2879-2886, 1989.

GRIFFITHS, D.A.T. Economic evaluation of health services. Rev. Epidemiol. Sante Publique, v.29, n.12, p.85-101, 1981.

GROBLER, M. Economic analysis: is it working? Aust. Prescr., v.22, n.3, p.50-51, 1999.

GOLD, M.R.; SIEGEL, J.E.; RUSSLE, L.B.; WEINSTEING, M.C. Cost-effectiveness in health and medicine. New York: Oxford University Press, 1996. 456 p.

JOHANNESSON, M.; LE LORIER, J. How to assess the economics of hypertension control programmes. J. Hum. Hypertens., v.10, supl.1, p.893-894, 1996.

JOLICOEUR, L.M.; JONES-GRIZZLE, A.J.; BOYER, J.G. Guidelines for performing a pharmacoeconomic analysis. Am. J. Hosp. Pharm., v.49, n.7, p.1741-1747, 1992.

LEATHERMAN S.; BERWICK D., ILES D.; LEWIN L.S.; DAVIDOFF, F.; THOMAS, N.; BISOGNANO, M. The business case for quality: Case studies and an analysis. Health Aff., v.22, n.2, p.17-30, 2003.

LEW, M.A.; FORGIA, G.M.; SULVETTA, M.B. Mensuring public hospital costs: empirical evidence from Dominican Republic. Soc. Sci. Med., v.43, n.2, p.221-234, 1996.

LOPERT, R.; LANG, D.L., HILL, S.R. Use of Pharmacoeconomics in prescribing research. Part 3: costeffectiveness analysis - a technique for decision making at the margin. J. Clin. Pharm. Ther., v.28, n.3, p.243-249, 2003. 
LOTTENBERG, C. A saúde brasileira pode dar certo: os caminhos para garantir um atendimento de qualidade, sustentável e acessível para toda a população. São Paulo: Atheneu, 2007. 128 p.

MANKIW, G.N. Introdução à economia: princípios de micro e macroeconomia. 2.ed. Rio de Janeiro: Elsevier, 2001. 831 p.

MÉDICI, A.C. Economia e financiamento do setor saúde no Brasil. São Paulo: Faculdade de Saúde Pública - USP, 1994. 218 p.

MILLS, A.; DRUMMOND, M.F. Economic evaluation of health programmes: a glossary of terms. World Health Stat. Q, v.38, n.4, p.432-434, 1985.

MOSSIALOS, E. Citizens' views on health care systems in the 15 member states of the European Union. Health Econ., v.6, n.2, p.109-116, 1997.

NATIONAL INSTITUTE FOR CLINICAL EXCELLENCE. Guidance for manufacturers and sponsors, 2001. Available at: http://www.nice.org.uk/pdf/technicalguidanceformanuf acturerstandsponsrs.pdf. Accessed on: 12 fev. 2004.

ORGANIZACIÓN MUNDIAL DE LA SALUD. OMS. Economía aplicada a la sanidad. Cuadernos de Salud Publica. Genebra: OMS, 1976. 53 p.

PASHOS, C.L.; KLEIN, E.G.; WANKE, L.A. ISPOR Lexicon. Princeton: International Society for Pharmacoeconomic and Outcomes Research, 1998. 72 p.

PINTO-PRADES, J.L.; ORTÚN-RUBIO, V; PUIG-JUNOY, J. El Análisis coste-efectividad en sanidad. Aten. Primaria, v.27, n.4, p.275-278, 2001.

PRZYBYLSKI, K.G.; RYBAK, M.J.; MARTIN, P.R.; WEINGARTEN, C.M.; ZARAN, F.K.; STEVENSON, J.G.; LEVINE, D.P. A pharmacist-initiated program of intravenous to oral antibiotic conversion. Pharmacotherapy, v.17, n.2, p.271-276, 1997.

REINHARDT, U.E. Making economic evaluations respectable. Soc. Sci. Med., v.45, n.4, p.555-562, 1997.

ROBERTSON, J.; LANG, D.; HILL, S. Use of pharmacoeconomics in prescribing research. Part 1: costsmoving beyond the acquisition price for drugs. J. Clin. Pharm. Ther., v.28, n.1, p.73-79, 2003.
ROBINSON, R. Cost-benefit analysis. Br. Med. J., v.307, n.6909, p.924-926, 1993a.

ROBINSON, R. Economic Evaluation and Health Care: what does it means? Br. Med. J., v.307, n.6905, p.670-673, 1993 b.

RUSSEL, L.B.; GOLD, M.R.; SIEGEL, J.E.; DANIELS, N.; WEINSTEIN, M.C. For the Panel on Cost-Effectiveness in Health and Medicine. The role of Cost-effectiveness analysis in health and medicine. J. Am. Med. Assoc., v.276, n.14, p.1172-1177, 1996.

SACRISTAN DEL CASTILLO, J.A. Farmacoeconomía y evaluación económica de medicamentos: introducción. In: SACRISTAN DEL CASTILLO, J.A.; LLACH, X.B.; ROVIRA, J.F. Farmacoeconomía: evaluación económica de medicamentos. Madrid: Editores Médicos,1995. cap.1, p.19-29.

SACRISTÁN, J.A.; ORTÚN, V.; ROVIRA, J.; PRIETO, L.; GARCÍA-ALONSO, F. Evaluación económica en medicina. Med. Clin., v.122, n.10, p.379-382, 2004.

TOWNSEND, R.J. Post-marketing drug research and development. Drug Intell. Clin. Pharm., v.21, n.1, p.134136, 1987.

UGÁ, M.A.D. Instrumentos de Avaliação Econômica dos Serviços de Saúde: alcances e limitações. In: PIOLA, S.F.; VIANNA, S.M. (Orgs.). Economia da Saúde: conceito e contribuição para a gestão da saúde. 3.ed. Brasília: IPEA, 2002. cap.9, p.209-226.

VENTURINI, F.; JOHNSON, K.A. Introduction to pharmacoeconomic principles and application in pharmacy practice. Calif. J. Health Syst. Pharm., v.14, n.1, p.6-14, 2002.

VIEIRA, F.S.; MENDES, A.C.R. Evolução dos gastos do Ministério da Saúde com medicamentos. Brasília: Ministério da Saúde. 2007. 33 p.

VILLAR, F.A. Evaluación económica aplicada a los medicamentos: características y metodologia. In: SACRISTAN DEL CASTILLO, J.A.; LLACH, X.B.; ROVIRA, J.F. (Eds.). Farmacoeconomía: evaluación económica de medicamentos. Madrid: Editores Médicos, 1995. cap.2, p.31-50. 
WALKER, D. Cost and cost-effectiveness guidelines: which one to use? Health Policy Plan, v.16, n.1, p.113-121, 2001.

WALLEY, T.; HAYCOX, A. Pharmacoeconomics: basic concepts and terminology. Br. J. Clin. Pharmacol., v.43, n.4, p.343-348, 1997.
ZANINI,A.C.; FARHAT, F.C.L.G.; RIBEIRO, E.; FOLLADOR, W. Farmacoeconomia: conceitos e aspectos operacionais. Rev. Bras. Cienc. Farm., v.37, n.3, p.225-237, 2001.

Received for publication on $16^{\text {th }}$ July 2010 Accepted for publication on $31^{\text {st }}$ January 2011 